TRIADIK

ISSN (print): 0853-8301; ISSN (online): 2745-777X

Available online at https://ejournal.unib.ac.id/index.php/triadik

DOI: https://doi.org/10.33369/triadik.v19i2.16458

page: $34-39$

\title{
Peran Kontrol Diri Dan Aktivitas Penggunaan Game Online Terhadap Prokrastinasi Akademik Pada Siswa MAN Bengkulu Utara
}

\author{
1Pera Viransi, 2I Wayan Dharmayana, ${ }^{3}$ Afifatus Sholihah
}

\author{
Universitas Bengkulu
}

\section{Korespondensi: peraviransi@gmail.com}

\begin{abstract}
Abstrak
Penelitian ini bertujuan untuk mendeskripsikan dan melihat hubungan peran kontrol diri dan aktivitas penggunaan game online terhadap prokrastinasi akademik pada siswa MAN Bengkulu Utara. Penelitian ini menggunakan deskriptif kuantitatif Teknik korelasi. Subjek penelitian ini berjumlah 149 siswa. Teknik pengumpulan data menggunakan kuesioner angket skala likert dan dokumentasi. Analisis data menggunakan Korelasi Ganda. Hasil penelitian yaitu (1) Siswa memiliki prokrastinasi akademik yang sangat tinggi (2) Siswa memiliki intensitas penggunaan game online yang sangat tinggi (3) kontrol diri yang sangat rendah (4) Terdapat $r_{\text {hitung }}-0.629$ dengan $p=0.000<\bar{\alpha} 0.05$ korelasi negatif yang signifikan antara kontrol diri dengan prokrastinasi akademik siswa (5) Terdapat $r_{\text {hitung }} 0.639$ dengan $\mathrm{p}=0.000<\bar{\alpha} 0.05$ korelasi positif yang signifikan antara aktivitas penggunaan game online dengan prokrastinasi akademik siswa (6) Hubungan yang signifikan yang negative antara kontrol diri dan aktivitas penggunaan game online dengan prokrastinasi akademik. Semakin rendah kontrol diri dan aktivitas penggunaan game online tinggi, semakin tinggi prokrastinasi akademik

Kata Kunci: Kontrol diri, Aktivitas penggunaan game online, Prokrastinasi akademik
\end{abstract}

\begin{abstract}
This study aims to describe and see the relationship between the role of self-control and the intensity of the use of online games on academic procrastination among students of MAN Bengkulu Utara. This research used descriptive quantitative correlation technique. The research subjects were 149 students. The data collection technique used Likert scale questionnaire and documentation. Data analysis using multiple correlation. The results showed that the general picture of the students' procrastination amounted to $50 \%$, the intensity level of using online games58\%, self-control amounted to $87 \%$, there is a significant negative correlation between self-control and academic procrastination, this is indicated by the results of the correlation test $r_{\text {count }} 0.629$ with $p=0.000$ $<\bar{\alpha} 0.05$, there is a significant positive correlation between the intensity of using online games and academic procrastination. this is shown from the results of the correlation $\mathrm{r}_{\text {count }} 0.639$ with $\mathrm{p}=0.000<\bar{\alpha} 0.05$.
\end{abstract}

Keywords: Self-control, intensity of using online games, Academic procrastination

\section{Pendahuluan}


Pendidikan merupakan suatu proses pembelajaran kepada siswa agar memiliki kepemahaman terhadap sesuatu hal, yang direncanakan secara sistematis, agar suasana belajar dan proses pembelajaran dapat dilaksanakan dengan optimal. Pada era globalisasi ini teknologi semakin maju, tidak dapat dipungkiri hadirnya internet semakin dibutuhkan dalam kehidupan seharihari, agar mempermudahkan manusia untuk memenuhi kebutuhannya secara instan. Hal ini cenderung menimbulkan rasa malas, jenuh dan membosankan sebab dengan adanya teknologi memungkinkan manusia bekerja lebih sedikit, sehingga memunculkan sikap menunda-nunda atau prokrastinasi (As-sidiq, 2012:511). Hasil penelitian menunjukkan bahwa prokrastinasi merupakan salah satu masalah yang menimpa sebagian besar anggota masyarakat luas, dan $75 \%$ dari pelajar, melaporkan bahwa prokrastinasi merupakan suatu masalah dalam lingkup akademis mereka (Aprianti et al., 2012:4). (Juyanti \& Aisyah, 2015:5) menyatakan prokrastinasi akademik adalah menunda dengan sengaja kegiatan yang diinginkan walaupun individu mengetahui bahwa perilaku penundaanya menghasilkan dampak buruk. Prokrastinasi ketidakmampuan untuk menggunakan waktu secara efektif yang mengakibatkan seseorang suka menunda-nunda pekerjaannya, suka bermalas-malasan, dan memboroskan waktu untuk halhal yang tidak penting.

Berdasarkan observasi pada siswa MAN 1 Bengkulu Utara yang melakukan prokrastinasi, siswa banyak yang menunda-nunda tugas sekolah padahal siswa tahu bahwa tugas harus segera diselesaikan, peneliti mewawancarai beberapa siswa disekolah mengatakan bahwa sering bermain game online hingga larut malam. Menurut (Putri \& Prasetyaningrum, 2018:7) tingkat aktivitas penggunaan game online di Indonesia membuat para pemainnya menjadi pecandu game online dan mengabaikan serta melupakan kegiatannya sehari-hari guna dapat bermain game online secara terus menerus. Menurut Henry (dalam Syahran, 2015: 3) penggunaan game online di Indonesia untuk produk dari PT. Lyto Datarindo Fortuna (LYTO), sudah mencapai 6 juta orang ini pada tahun 2015. Menurut (Mahardika et al., 2018:7) remaja merupakan salah satu penggunaan game online aktif yang menjadi target pemasaran distributor game. Indonesia orang bermain game online diperkirakan 15 juta pengguna pada tahun 2018. Hasil observasi pada siswa MAN 1 Bengkulu Utara menunjukkan banyaknya fenomena bermain game online. Siswa yang mudah memilki applikasi game online di smart phone bermain game online bisa menghabiskan sebagian besar aktivitas waktunya hanya untuk bermain game online tidak menghiraukan aktivitas lain yang lebih penting seperti makan, minum dan dilihat dari siswa yang banyak memanfaatkan waktu istirahat dengan bermain game online didalam kelas bahkan ada beberapa siswa yang sulit menahan ajakan teman untuk bermain game online pada saat jam kosong maupun waktu istirahat. Game online sendiri merupakan wadah bermain yang sangat digemari remaja sehingga disebut dengan istilah anak gamers membuat remaja tertarik masuk dalam wadah tersebut dibuktikan dengan banyaknya remaja sering menghabiskan waktu dengan smart phone dari pada buku, sehingga menyebabkan aktivitas sekolah terganggu, kebanyakan siswa menunda-nunda tugas, maka tidak sedikit siswa yang lemah dalam mengontrol dirinya. Menurut (Maahardika et al., 2018:54) kontrol diri merupakan potensi yang dimiliki setiap orang yang dapat berkembang sesuai dengan kemauan individu tersebut. 
Tujuan penelitian ini untuk melihat gambaran prokrastinasi akademik, melihat tingkat kontrol diri dan aktivitas penggunaan serta melihat adakah hubungan antara kontrol diri dengan prokrastinasi akademik dan melihat adakah hubungan antara aktivitas penggunaan game online dengan prokrastinasi akademik.

\section{Metode Penelitian}

Metode yang digunakan pada penelitian ini adalah metode deskriptif kuantitatif, dengan Teknik korelasi. Teknik korelasi adalah suatu penelitian yang dilakukan dengan mengumpulkan sejumlah data untuk mengetahui serta menentukan ada tidaknya hubungan antara tiga variable yang diukur tersebut (Darmadi, 2014:206).

Jumlah populasi pada penelitian ini adalah siswa kelas XI dan XII di MAN 1 Bengkulu Utara berjumlah 237 siswa. Sampel penelitian ini berjumlah 149 siswa. Prosedur pengambilan sampel ini menggunakan teknik sampling yang digunakan adalah classter random samping ini merupakan teknik pengambilan sampel dengan mengacak kelompok/kelas.

Teknik pengumpulan data dalam pendekatan kuantitatif pada penelitian ini dilakukan menggunakan skala dengan model likert. Validitas adalah suatu data dapat dipercaya kebenarannya sesuai dengan kenyataan. Menurut (Sugiyono 2010: 176) valid berarti instrument tersebut dapat digunakan untuk mengukur apa yang seharusnya diukur. Uji validitas yang digunakan dalam penelitian ini adalah validitas isi yang dilakukan oleh 2 ahli. Sebelum kuisioner diberikan kepada kelas yang menjadi populasi, instrument terlebih dahulu diujicobakan kepada kelas lain sebanyak 40 siswa dengan menggunakan aplikasi SPSS versi 16.0.

Pada penelitian ini uji coba digunakan rumus korelasi jika $r_{\text {hitung }} \geq r_{\text {tabel }}$ maka data dikatakan valid, tapi jika $r_{\text {hitung }} \leq r_{\text {tabel }}$ maka data tidak valid (Winarni, 2011: 193). Sampel uji coba dalam penelitian ini memiliki variabel kontrol diri (X1) dengan 31 item pernyataan melalui bantuan SPSS 16.0 yang tidak valid pada butir soal nomer 4 dan 24 . Variabel aktivitas penggunaan game online (X2) Dengan 19 item pernyataan yang tidak valid pada butir soal nomer 9, 10, 11, 14, 16, 18. Variabel prokrastinasi akademik (Y) dengan 37 item penyataan yang tidak valid pada butir soal nomer 25 .

Pada penelitian ini diperoleh Cronbach's Alpa. Menurut Ghozali (dalam Muzakky, 2015: 84) suatu konstruk atau variabel dinyatakan reliabel jika cronbach's alpha $>0,7$. Untuk kontrol diri (X1) berjumlah 0.798, aktivitas penggunaan game online (X2) bejumlah 0.783 dan prokrastinasi akademik (Y) berjumlah 0.886 berarti dinyatakan reliabel pada ketiga variable tersebut.

Pada penelitian ini analisis data setelah data yang diperlukan tekumpul, maka langkah selanjutnya adalah menganalisis data tesebut. Langkah ini menjadi penting mengingat analisis data sangat diperlukan erat kaitannya dengan proses penarikan kesimpulan suatu penelitian. Dalam penelitian ini, Teknik yang digunakan ialah Korelasi Ganda. Uji hipotesis dengan bantuan program computer yaitu SPSS versi 16.0. Kriteria penerimaan atau penolakan hipotesis adalah jika nilai Sig.(2-tailed) $<0,05$ maka $\left(\mathrm{H}_{0}\right)$ ditolak dan $\left(\mathrm{H}_{\mathrm{a}}\right)$ diterima.

\section{Hasil dan Pembahasan}


Deskripsi data yang disajikan dalam penelitian ini adalah dengan deskripsi data terdiri dari tiga variable yaitu 2 variabel bebas yaitu kontrol diri dan aktivitas penggunaan game online dan 1 variabel terikat yaitu prokrastinasi akademik. Kuesioner kontrol diri terdapat 29 item dengan pilihan jawaban 3 pilihan yang bergerak dari 1-3 sehingga diperoleh rentang minimum adalah $29 \times 1=29$, maximum adalah $29 \times 3=87$, sehingga luas jarak sebarannya adalah $87-29=58$, dengan demikian setiap satuan deviasi srandartnya bernilai $\bar{\alpha}=58 / 6=9.7$ dan mean idealnya adalah 58 . Sedangkan kuesioner aktivitas penggunaan game online dengan 5 pilihan jawaban bergerak 1-5 sehingga diperoleh rentang minimum adalah $13 \times 1=13$, maximum adalah $13 \times 5=65$, sehingga luas jarak sebarannya adalah $65-13=52$, dengan demikian setiap satuan deviasi srandartnya bernilai $\bar{\alpha}=52 / 6=8.8$ dan mean idealnya adalah 39. dan prokrastinasi akademik dengan 5 pilihan jawaban, bergerak 1-5 sehingga diperoleh rentang minimum adalah $36 \times 1=36$, maximum adalah $63 \times 5=180$, sehingga luas jarak sebarannya adalah $180-36=144$, dengan demikian setiap satuan deviasi srandartnya bernilai $\bar{\alpha}=144 / 6=24$ dan mean idealnya adalah 108. Dari hasil tersebut dapat disimpulkan bahwa diketahui dari 149 responden yang menjadi sampel penelitian. Tingkat prokrastinasi akademik pada siswa bejumlah 74 responden dengan pesentase $50 \%$. Tingkat kontrol aktivitas penggunaan game online sisswa berjumlah 86 responden dengan persentase (58\%). Serta tingkat kontrol diri siswa berjumlah 129 responden dengan persentase (87\%).

Melihat hubungan antara variabel bebas dan terikat sebagai berikut:

Tabel 1

Korelasi antar variabel

\begin{tabular}{|ll|r|r|r|}
\hline & & \multicolumn{1}{|c|}{ KD } & \multicolumn{1}{c|}{ IP } & \multicolumn{1}{c|}{ PA } \\
\hline KD & Pearson & 1 & $.605^{* *}$ & $-.629^{* *}$ \\
& Correlation & & & \\
& Sig. (2-tailed) & & .000 & .000 \\
& $\mathrm{~N}$ & 149 & 149 & 149 \\
\hline IP & Pearson & $.605^{* *}$ & 1 & $.639^{* *}$ \\
& Correlation & & & .000 \\
& Sig. (2-tailed) & .000 & & 149 \\
& $\mathrm{~N}$ & 149 & 149 & 1 \\
\hline PA & Pearson & $-.629^{* *}$ & $.639^{* *}$ & 1 \\
& Correlation & .000 & .000 & \\
& Sig. (2-tailed) & 149 & 149 & 149 \\
& $\mathrm{~N}$ &
\end{tabular}

Berdasarkan tabel 1, dapat disimpulkan bahwa terdapat hubungan antara kontrol diri dengan prokrastinasi akademik terlihat nilai sig.(2-tailed) antara variabel kontrol diri dengan prokrastinasi akademik adalah $\mathrm{p}=0.000<$ $\bar{\alpha}=0.05$ berarti Ho ditolak, yang berarti terdapat korelasi yang signifikan antara variabel kontrol diri dengan prokrastinasi akademik. Lalu tedapat juga hubungan antara aktivitas penggunaan game online dengan prokrastinasi akademik terlihat nilai sig.(2-tailed) antara variabel aktivitas penggunaan 
game online dengan prokrastinasi akademik adalah $\mathrm{p}=0.000<\bar{\alpha}=0.05$ berarti Ho ditolak, yang berarti terdapat korelasi yang signifikan antara variabel aktivitas penggunaan game online dengan prokrastinasi akademik.

\section{Kesimpulan dan Saran}

1. Gambaran secara umum tentang prokrastinasi akademik siswa MAN 1 Bengkulu Utara adalah siswa memiliki prokrastinasi akademik yang sangat tinggi berjumlah 74 responden (50\%). Gambaran secara umum tentang aktivitas penggunaan game online siswa MAN 1 Bengkulu Utara adalah siswa memiliki aktivitas penggunaan game online yang sangat tinggi berjumlah 86 responden (58\%). Gambaran secara umum tentang kontrol diri siswa MAN 1 Bengkulu Utara adalah siswa memiliki kontrol diri yang sangat rendah berjumlah 129 re sponden (87\%). Terdapat korelasi rhitung 0.629 dengan $\mathrm{p}=0.000<\bar{\alpha} 0.05$ sehingga Ha diterima dan Ho ditolak, terdapat korelasi negatif yang signifikan antara kontrol diri dengan prokrastinasi akademik siswa. Semakin rendah kontrol diri maka semakin tinggi prokrastinasi akademik siswa MAN 1 Bengkulu Utara. Terdapat korelasi rhitung 0.639 dengan $\mathrm{p}=0.000<\bar{\alpha} 0.05$ sehingga Ha diterima dan Ho ditolak, terdapat korelasi positif yang signifikan antara aktivitas penggunaan game online dengan prokrastinasi akademik siswa Semakin tinggi aktivitas penggunaan game online maka semakin tinggi prokrastinasi akademik siswa MAN 1 Bengkulu Utara. Hubungan yang signifikan yang negative antara kontrol diri dan aktivitas penggunaan game online dengan prokrastinasi akademik. Semakin rendah kontrol diri dan aktivitas penggunaan game online tinggi, semakin tinggi prokrastinasi akademik.

\section{Daftar Pustaka}

Aprianti, K. D., Ini, S., Sebagai, D., Satu, S., Untuk, P., \& Gelar, M. (2012). "Hubungan Antara Dukungan Sosial Orangtua Dengan Prokrastinasi Akademik Dalam Menyelesaikan Skripsi Pada Mahasiswa Pendidikan Tata Niaga Fakultas Ekonomi Universitas Negeri Jakarta" Jounal.

Azwar, S. (2012). Penyusunan Skala Psikologi (ed 2). Yogyakarta: Pustaka Pelajar.

Darmadi, H. (2014). Dimensi-dimensi metode penelitian Pendidikan dan social (konsep dasar dan implementasi). Bandung: Alfabeta.

Drajat E. K. (2017). "Pengaruh Intensitas Bermain Game Online Terhadap Perilaku Prokrastinasi Akademik Pada Mahasiswa Bimbingan dan Konseling Universitas PGRI Yogyakarta". Jurnal Konseling GUSJIGANG, 3(1), 98. https://doi.org/10.24176/jkg.v3i1.1120

Erizka, Martunis, Abu Bakar. (2019). "Korelasi Intensitas Bermain Game Online Mobile Legend Dengan Keterampilan Sosial Siswa Man 3 Banda Aceh". Skripsi Universitas Syiah Kuala. Vol. 4 No 3. Hal:62. file:///E:/SKRIPSI/reverensi\%20bab\%202/10118-28213-1-PB.pdf

Ika W. T. \& Najlatun. N. (2020). "Hubungan Antara Kontrol Diri dan Perilaku Asertif dengan Prokrastinasi Akademik Peserta Didik Kelas IX SMP Negeri 34 Surabaya". Skripsi Universitas Negeri Surabaya. file://E:/SKRIPSI/reverensi\%20ba b\%202/31632-37871-1-PB.pdf 
Julyanti, M., \& Aisyah, S. (2015). "Hubungan Antara Kecanduan Internet Dengan Prokrastinasi Tugas Sekolah Pada Remaja Pengguna Warnet di Kecamatan Medan Kota”. Jurnal Diversita, Vol. 1(No. 2)

Leilly P. R. (2018). "Pengaruh Pola Asuh Orang Tua dan Kontrol Diri Terhadap Perilaku Agresif Pada Remaja SMP Negeri 27 Samarinda". Skripsi Universitas Mulawarman. Vol 6. No 2: Hal:323. ejournal.psikologi.fisip-unmul.ac.id

file:///E:/SKRIPSI/reverensi\%20bab\%202/JURNAL\%20LEILLY\%20(0828-18-09-44-52).pdf 